\title{
Sonhar o destino: projetos e impasses sobre a grandeza de Portugal
}

\author{
Jacqueline Hermann*
}

LIMA, Luís Filipe Silvério. O império dos sonhos. Narrativas proféticas, sebastianismo \& messianismo brigantino. São Paulo: Alameda, 2010.

"Século dos sonhos", título da última parte do livro de Luís Filipe Silvério Lima, resume bem a tese defendida pelo autor, e expressa os vários sentidos e questóes que seu trabalho propóe: identificar, analisar e cotejar as narrativas oníricas produzidas em Portugal no que chamou de "longo século XVII”. Longo porque se inicia depois de 1580 e termina com o reinado de d. Joáo V, em 1750, tendo por eixo o sentido e o papel assumidos pelos sonhos na origem da história sagrada do reino luso, seus impasses e expectativas como Monarquia ou Império Universal. Para conduzir e consumar esse "destino", um soberano português, vivo, morto ou ressuscitado desempenharia a grandiosa tarefa determinada pela insondável vontade divina.

Às grandes questóes já enunciadas agrega-se outra não menos complexa: a que estabelece a relação entre sonho e profecia, desejo e destino, vivência individual e sentido coletivo da "revelação onírica”. O sonho como expressão e tradução do sintoma de um tempo atravessado por crises de matizes variados, desafios inesperados e projeçóes que passaram da convicção orgulhosa à melancolia de uma espera reiteradamente frustrada, raiz profunda de um dos muitos sentidos atribuídos à história portuguesa. A interpretaçáo dos sonhos proféticos teve impacto político — e religioso — " "para expli- car e justificar a especificidade portuguesa diante das nações cristãs", assumindo em Portugal papel estrutural nas "formulaçôes político-providencialistas que organizaram e justificaram a ideia de reino e nação portuguesa", defende o autor.

A tese é ousada, levanta questóes que só a valorizam, e tem base sólida: parte de um caminho pavimentado com segurança e atençáo, vigilante e inebriado pela análise dos sonhos do missionário Francisco Xavier feita pelo grande Antônio Vieira, em fins do século XVII. Com a verve que o celebrizou, Vieira perguntou-se, na "Conclusão" aos três sermóes de Xavier Dormindo, se não haveria contradição entre as imagens biográficas que apresentavam o já santo Francisco Xavier sempre dormindo e sonhando, e a esperada "imagem da perfeita vigilância" e "os olhos sempre abertos" de um bem-aventurado de Deus. Resposta: Xavier era o maior de todos os santos até mesmo dormindo porque em seus sonhos cuidava "da missão cristã no passado, por meio da memória de seus atos; no presente, por meio dos resquícios da sua vigília; e no futuro, por meio da iluminação divina pela profecia”. O autor parte, portanto, de Vieira e de seu projeto de Império Universal: processado pela Inquisição de Coimbra entre 1663 e 1667, manteve a defesa do sonho do Quinto Império, liderado por d. João IV ressuscitado, convicção que foi cedendo lugar a uma Monarquia Universal menos atrelada ao destino ou à identidade portuguesa.

A reflexão ampliada e adensada sobre a relação entre sonho-profecia-destino português foi, por-

* Doutora em história pela Universidade Federal Fluminense, professora associada da Universidade Federal do Rio de Janeiro, bolsista de produtividade científica do CNPq, nível 2. Rio de Janeiro, RJ, Brasil. E-mail: jacquehermann@uol.com.br. 
tanto, amadurecida na formação de Luís Filipe Silvério Lima, cujo resultado de maior fôlego temos agora neste $O$ império dos sonhos, versão de sua tese de doutoramento. Além do aprofundamento da análise, é de ressaltar a notável, variada e ampla pesquisa documental - incluindo fontes textuais e iconográficas - , reunida em acervos brasileiros e portugueses, identificada e comentada em valioso e raro anexo. Trata-se de verdadeiro guia para novas pesquisas relacionadas à temática das narrativas oníricas, indicando um formato original e que poderia inspirar outros pesquisadores.

O caminho para analisar tão vasta e diversificada documentação procurou entender os indícios e manifestaçôes oníricas como narrativas a um só tempo imaginadas/sonhadas e passíveis de realizaçáo, numa chave que fez do sonho um atalho para a revelação profética. Essa não era, no entanto, a única acepção para explicar o transe capaz de, "mesmo adormecido", revelar algo espiritual ou divino: havia a possibilidade, ou o risco, de que se tratasse de premeditada confusão demoníaca ou "resquício de vigília", entrega incompleta à profundidade do sono e do sonho. Silvério Lima nos apresenta um cenário envolvido na bruma que fez confluir o sonho e a profecia, a indicar a vitória e a força dessa relação na história do destino da monarquia portuguesa desse longo Seiscentos.

Dividido em três partes, começa procurando decifrar o que chama de "a semântica e a retórica" das narrativas proféticas selecionadas. Em "Imagens da enunciação" identifica a recorrência de textos sobre as narrativas oníricas acerca da origem e do destino do reino luso a partir de fins do século XVI, cujo marco mais expressivo, reiterado e duradouro, foi o Milagre de Ourique. Neste evento "fundador" da história da grandeza portuguesa, na verdade valorizado como lenda da origem sagrada do reino a partir do século XV até então apenas sua dimensão militar era destaca$\mathrm{da}-$, um novo documento aparece para "sancionar" o feito e suas consequências: o Juramento de Afonso Henriques, documento "legal" que superou a narrativa lendária e épica, pois inseriu o primeiro dos reis portugueses na racionalidade de uma monarquia "escolhida" para um destino atrelado à vontade inquestionável das determinações divinas. De forma resumida, o "milagre" teria se configurado a partir do aparecimento, primeiro em sonho, depois em vigília, de Cristo a Afonso Henriques na véspera da batalha contra contingente de mouros muito superior ao de portugueses. A vitória improvável dos lusitanos marcou o início da autonomia do pequeno reino e o caráter cruzadístico da façanha. De batalha a milagre, Ourique se consolidou como um dos mitos de origem de Portugal, desdobrou-se em inúmeras crônicas e narrativas sobre o assegurado destino grandioso do reino e, variando no tempo, de seu império.

Além de Ourique, ganharam destaque nesse mesmo período as Trovas do sapateiro Gonçalo Annes Bandarra, que viria a ser considerado por ninguém menos que Antônio Vieira verdadeiro profeta da unidade católica universal portuguesa. Luís Filipe Silvério, para manter-se no recorte de fins do XVI e início do XVII, utiliza aquela que foi considerada a primeira edição de parte dos versos de Bandarra, publicados em Paris pelo fidalgo d. João de Castro, cuja participação na conjuntura política da época explica pelos menos parcialmente seu interesse pelos escritos do sapateiro. Como Ourique, no entanto, as tais trovas circulavam manuscritas desde pelos menos meados do século XVI, quando Bandarra foi processado e condenado pela Inquisição portuguesa por fazer livre interpretação da sagrada escritura. Intriga não ter sido acusado de judaísmo, pois vivia entre cristáos recém-conversos, tinha fama de ser "verdadeiro rabi" pelo conhecimento dos livros sagrados dos hebreus. A interpretação feita por Castro desconsiderou essa origem, provável base do messianismo régio anunciado pelo sapateiro, reiteradamente proibido e divulgado entre letrados e populares. A senda seguida por Silvério Lima segue esse viés, depurado do judaísmo, e sempre controverso quanto à identidade do rei messias da unidade católica. Combinação contraditória e no limite herética, foi gradativamente esvaziada do possível viés judaico, incorporada às reinterpretaçóes cristianizadas de elementos heterodoxos. A longevidade dos escritos de Bandarra, a continuada "descoberta” de novos corpos de versos no século XVIII e as 
reedições do século XIX dão bem a dimensão do enraizamento do personagem e da lógica de sua espera entre os portugueses. As trovas de Bandarra teriam sido inspiradas ou reveladas em sonhos.

A terceira vertente trilhada por Lima é a das projeçôes de Portugal como cabeça da Quinta Monarquia ou do Quinto Império do Mundo, variaçóes alteradas pelas muitas formulaçóes que conheceu no período. O mesmo João de Castro que valorizou Bandarra defendeu a tese da Quinta Monarquia, operando a convergência desses veios de sonhos, consolidada pela grandeza retórica de Antônio Vieira, defensor da tese do Quinto Império. Para o famoso jesuíta, o sapateiro profeta previra ser d. Joáo IV o Encoberto das trovas; a ressurreição do primeiro Bragança para cumprir o destino do império português foi agregada por Vieira mais de um século depois das primeiras notícias dos escritos de Bandarra.

A teia de narrativas, versóes e reinterpretaçôes ancoradas nesse tripé são o foco da segunda parte do livro, "Destinos de Portugal", base aliás que sustenta a tese do longo século XVII. Silvério Lima analisa as tópicas dessas narrativas, todas oriundas de projeçôes oníricas, procurando entender como se fundiram ou dialogaram para confirmar a profecia reveladora da grandeza da monarquia e do império português. Sim, porque embora a ideia da Quinta Monarquia tenha cedido força à crença do Quinto Império em Portugal expectativa disseminada pela Europa, a exemplo dos pentamonarquistas ingleses, aspecto também discutido pelo autor —, nas formulaçôes de Vieira, Monarquia e Império aparecem completamente fundidos, são partes complementares de um só destino: só uma monarquia especial poderia sediar um império universal católico; só um rei que já cumpriu parte da profecia - a Restauração - poderia terminar a obra já iniciada. A experiência e a história confirmavam a previsão do futuro sonhado, confirmavam a História do futuro.

A terceira parte do livro, "Tempo dos sonhos", pretende esmiuçar não o que unificou essas narrativas, mas seus pontos de atrito e de ruptura. Trata, portanto, dos tempos de esgarçamento dessa rede de projeçóes reiteradas e realimentadas, ana- lisados através das crônicas e da historiografia, que entre o final do século XVI e o início do XVIII, elaborou uma cronologia dos vários momentos dos sonhos proféticos da grandeza do rei e da monarquia portuguesa. O século XVIII - fim do longo "Século dos sonhos" —, sobretudo a partir da segunda metade, vive o que o autor chamou de "crepúsculo do discurso-onírico-profético". As concepçóes da grandeza portuguesa fundadas na providência divina passam a sofrer continuadas críticas, pondo-se em dúvida o pilar estrutural da construção sagrada do destino português: o Milagre de Ourique. O grande evento perde centralidade até ser rebaixado a nota de rodapé em obras de grandes autores portugueses do século XIX, a exemplo de Alexandre Herculano em sua História de Portugal, de 1846. A reação de inúmeros religiosos gerou polêmica conhecida que só confirma a luta tardia pela sobrevivência do "milagre" da origem lusa.

O XVIII teria sido, portanto, o início do tempo de vigília contra o que passou a ser considerado obscurantismo e irracionalidade, embora a defesa ou crença na profecia dos antigos sonhos tenha sobrevivido e mesmo se fortalecido em algumas conjunturas inesperadas, como no contexto das invasôes napoleônicas. No início do século XIX, uma renovada lufada providencialista sacudiu o reino e reacendeu a polêmica sobre o destino sagrado de Portugal, novas versóes das Trovas de Bandarra foram editadas, dentro e fora do reino, e o debate sobre a possível volta de $\mathrm{d}$. Sebastiáo ocupou as prensas de várias tipografias portuguesas. Vale assinalar, no entanto, que na longa duração o esperado foi, quase sempre, d. Sebastião, não tendo d. João IV a longa carreira do Desejado no horizonte sonhado ou projetado para Portugal. Pode-se dizer até que o messianismo brigantino dependeu sempre e quase exclusivamente de Vieira, que, se o imortalizou em seus escritos, não foi capaz de produzir seguidores, como aconteceu com d. Sebastião.

Nos últimos capítulos do livro, Silvério Lima faz um balanço da historiografia dedicada aos dois messianismos concorrentes estruturados no século XVII: o sebastianista e o brigantino. $\mathrm{O}$ primeiro 
produzido no curso dos desdobramentos do desastre de Alcácer Quibir e do desaparecimento de d. Sebastiâo, em 1578; o segundo surgido nas primeiras décadas do XVII, quando o Encoberto das trovas de Bandarra passou a ser identificado entre os herdeiros da Casa de Bragança, ainda no tempo do domínio Habsburgo em Portugal. E aqui chamo atenção para o tardio surgimento do tema da Uniáo Ibérica na argumentação elaborada por Lima. Isso porque o tempo alto dos sonhos proféticos analisados e sua relação com a história e o destino de Portugal como cabeça de um império católico são relembrados, reelaborados e reinterpretados no contexto de uma derrota e diante da insegurança sobre o presente. Sonhar o passado profetizado para projetar o futuro foi resultado desse tempo de falta de um rei natural e de ameaça à integridade do reino ou expressão particular lusitana longa e lentamente constituída? No despertar do império dos sonhos de Lima, a união das Coroas Ibéricas entra como um dado do contexto, não como motor das versóes a um só tempo esperançosas e melancólicas da grandeza perdida, sempre ansiada, sonhada, sempre adiada.

Outra questão aberta por estes sonhos Seiscentistas, e já aqui indicada, refere-se ao que chamei de depuração da provável base judaica do messianismo bandarrista e, por consequência, em seus desdobramentos sebastianistas ou brigantinos. Silvério Lima parte de um sapateiro-profeta já totalmente cristianizado, recuperado por d. João de Castro, primeiro a imprimir parte dos versos atribuídos a Bandarra. Vale relembrar, como já mencionado, que suas previsóes ou profecias são anteriores à União Ibérica e ao contexto que levou Castro a migrar da defesa dos direitos de $\mathrm{d}$. Antônio, prior do Crato, à sucessão de Portugal na crise política decorrente da derrota de Alcácer Quibir, para o campo do Encoberto d. Sebastião. A defesa de Bandarra pelo "corifeu do sebastianismo", como Castro foi chamado por João Lúcio de Azevedo, teve endereço certo, e se é verdade que se alimentou dessa semântica mais ampliada de sonho partilhada pelas narrativas selecionadas, fazia política no sentido mais exato da palavra e sua participação na defesa do falso d. Sebastião de
Veneza parece confirmar essa interpretação. Nesse mesmo recorte temático e cronológico, chama atenção a importância concedida ao mencionado d. Antônio, ou ainda à sua morte, em 1595, como marco da consolidação do "discurso sebastianista”. Fica clara a relação estabelecida por Silvério Lima entre a adesão ou ruptura de d. Joáo de Castro com a resistência antonista e a "conversáo" ao sebastianismo. Pode-se perguntar, no entanto, se não foi o antonismo, antes mesmo da morte do prior do Crato, derrotado pela crescente, subterrânea e nem sempre facilmente identificável onda de sebastianismo que adentrava as casas dos que esperavam a volta do rei e de seu exército do Norte da África.

Por fim, destaco o debate aberto acerca das relaçóes entre a proposta da Quinta Monarquia sebastianista, defendida por João de Castro, e o Quinto Império de Vieira, a ser liderado por d. João IV. O messianismo brigantino teria sido uma variação tardia do sebastianismo, indicando uma matriz comum, ou "algo particular", como defende o autor, traduçáo de um projeto relacionado diretamente à Casa de Bragança, "que reformulou a ideia de destino português"? Mais ainda, teria reformulado o próprio sebastianismo, uma vez que o termo Quinto Império "tornou-se preponderante" para identificar Portugal como potência cristã ultramarina. Ora, talvez por defender os "direitos" sebásticos na elaboração desse longo processo, penso ser difícil imaginar o surgimento do messianismo brigantino sem sua versão anterior ancorada na espera de d. Sebastiáo. A unir as duas modalidades, as trovas de Bandarra e suas múltiplas apropriaçôes ao longo dos séculos. No balanço final, e se é verdade que o termo Quinto Império se sobrepôs ao da Quinta Monarquia nas projeçóes posteriores de homens letrados, o mesmo não se pode dizer sobre "sobrevivência" de um "joanismo" como espera consolidada, o que parece inegável no caso do sebastianismo, até hoje citado para, por exemplo, explicar as bases de movimentos brasileiros, como o de Canudos.

$\mathrm{O}$ teor dos questionamentos aqui levantados, talvez um tanto herméticos para um público não iniciado, e todas as várias qualidades já destacadas 
indicam a importância da obra e do rico veio de pesquisa aberto para os estudos dos messianismos luso-brasileiros. Novos trabalhos de Silvério Lima sobre as tópicas presentes nesse conjunto de narrativas, cujas temáticas ultrapassaram o mundo ibérico, têm já demonstrado o vigor desse novo campo de investigação. Mais que bem-vindo, $O$ império dos sonhos nos ajuda a descortinar novas possibilidades e caminhos para a historiografia brasileira. 